Sport, body and power: Reassessing the myth of President Kekkonen

\author{
Wuokko, Maiju
}

2011-11

Wuokko , M 2011 , ' Sport, body and power: Reassessing the myth of President Kekkonen ', Norma: International Journal for Masculinity Studies , vol. 6 , no. 2 , pp. 124-140 . < http://www.idunn.no/ts/norma/2011/02/art07 >

http://hdl.handle.net/10138/29167

publishedVersion

Downloaded from Helda, University of Helsinki institutional repository.

This is an electronic reprint of the original article.

This reprint may differ from the original in pagination and typographic detail.

Please cite the original version. 


\section{norma | Nordic Journal for Masculinity Studies}

Vol. 06, Issue 2, 2011, 124-140

Universitetsforlaget AS, Oslo

\section{Maiju Wuokko \\ Sport, body and power: Reassessing the myth of President Kekkonen}

\section{Abstract}

Former President of Finland Urho Kekkonen was not only a powerful politician but also a well-known sportsman and keep-fit enthusiast. The president's sports hobbies were covered and celebrated in the media and thus became an integral part of his public persona. This paper looks at Kekkonen's athletic and able-bodied image and its significance for his power from the perspective of gender. In his exercise activities, Kekkonen was able to display his bodily prowess and demonstrate his version of masculinity, which emphasized both physical and mental strength. The union of mind and muscle in turn buttressed his political ascendancy. Kekkonen's athletic body served as a cornerstone of his dominance over his country and, simultaneously, as a shield protecting Finland from both internal and external threats.

Furthermore, Kekkonen's sports performances were essential elements in the myth that was created around the president during his term and which was carefully conserved after his fall from power. Drawing upon scholarship on men and masculinities, this paper reassesses the still-effective mythical image of Kekkonen as an invincible superman. The article reveals the performative nature of his athletic activities and shows that in part, his pre-eminence in them was nothing more than theatre enacted by him and his entourage. Thus, Kekkonen's superior and super-masculine image was actually surprisingly vulnerable and dependent on the success of the performance. The president's ageing, in particular, demonstrates the fragility of his displays of prowess, strength and masculinity, and shows how fragile the entanglement of body and power can be.

\section{Keywords:}

Urho Kekkonen, myth, masculinity, sport, exercise, body, power, ageing 


\title{
Sport, body and power: Reassessing the myth of President Kekkonen
}

\author{
Maiju Wuokko \\ maiju.wuokko@helsinki.fi
}

... [he] has maintained the physical condition of a brisk 40-year-old and his long, lean 'thinker's' arms contrast with his 'carpenter's' body. Every morning, he goes running in the forest surrounding his apartment; he high jumps, skis, fishes and hunts. In the hall, a catch from the forest is waiting: the antlers of an elk that [he] has shot in the surroundings of Yalta...

Is this, perhaps, a depiction of the strongman of Russian politics, Vladimir Putin? The portrayal would no doubt suit Putin well - he has, after all, often hit the international press headlines with his athletic displays of machismo (e.g. Halpin 2009, Osborn 2010, Parfitt 2010). But Putin is not the first political leader to utilize performances of sporting prowess in the creation of his public image. Probably the best-known example from history is the President of the United States Theodore Roosevelt, who constructed himself an exaggerated masculine image through leading a 'strenuous life' and participating in manly exercises such as boxing, wrestling, hiking, hunting and riding. Roosevelt succeeded so well in the masculinization of his public persona that he is still invoked as an embodiment of the turn-of-the-20th-century manliness (Bederman 1995, Testi 1995).

A Finnish counterpart for Roosevelt is President Urho Kekkonen, whom the above quote in fact portrays (Pajunen 1962). ${ }^{1}$ In this article, I examine Kekkonen's athletic and able-bodied image and its significance for his power in the light of men and masculinities studies.

Urho Kaleva Kekkonen (1900-1986) was the President of the Republic of Finland for a quarter of a century ${ }^{2}$ and is one of the best-known Finnish statesmen of all time. Yet, Kekkonen was not 'only' a politician but also a renowned sportsman and keep-fit enthusiast. Kekkonen's excellent physical condition and his regular outdoor activities were an integral part of his public persona. In particular, the president's reputation as a skier reached legendary proportions.

Kekkonen's public image was carefully controlled by the president and his office. The image stressed not only Kekkonen's political power but also his down-to-earth manners and folksy sense of humour. Very early on, the image building turned into conscious myth-making and eventually, some kind of political personality cult was born around 
Kekkonen (Herlin 1993, Lähdesmäki 2009). Today, Kekkonen is perceived as a largerthan-life figure whose myth is still strong, with the president's imposing physical appearance and supposed supremacy in everything he did as its fundamental ingredients. Several writers have recognized Kekkonen's 'mythicality' but as yet, no one has analysed the issue thoroughly (Tuikka 2007, 9). Obviously, this paper cannot exhaust the subject but only open the discussion; my aim is to suggest one possible means of critical reassessment of the president's myth.

The relation between myth and history is tight but ambiguous. Traditionally, historians have conceived of myths as unexamined or uncriticized assumptions about the past, which the historians were to dismantle and replace with historical truth. The idea of singular historical truth has, however, been proven untenable (at the latest) by postmodernism, and it no longer seems possible to dichotomize myth and history in terms of truth and falsity (Collins 2003, Heehs 1994). But myths can also be understood neutrally as inter-subjective belief systems that carry great political and social significance (Kanerva 1994, 150). This definition is well suited for the examination of President Kekkonen and I use the term in this sense when referring to his mythicality.

Even though substituting myths with historical truth is impossible, myths can - and should - still be critically discussed. However, the most fruitful approach is not to deliberate their correspondence with reality but discuss their meaning and magnitude (Jokisipilä 2005, 21). Thus, I do not intend to offer a new truth about Urho Kekkonen to replace old misconceptions but to assess the wider implications of his mythical image.

A central element in the myth of Kekkonen is his allegedly insuperable ability in sport. In this paper, I examine the linkages between the president's exercise hobbies, public image and political power. How was Kekkonen's image as a talented sportsman connected to his power position? How did the president's athletic body function as a building block for his public persona and for his authority over Finland? And how did the status of sport change in these respects during Kekkonen's term?

Gender perspective makes the connection between Kekkonen's body and power visible. In his sporting performances, the president simultaneously constructed his version of masculinity, which emphasized the union of mind and muscle and stressed both his physical and mental strength. This combination was crucial to the president's public image and even his power position. Kekkonen is as an excellent case study on the entanglement of power, body and masculinity. His example demonstrates how an athletic masculine body can serve as a source of political authority and power. But at the same time, ageing Kekkonen shows how vulnerable this connection can be.

The president's athletic body also played (and still plays) a central role in the (re)construction of his myth: narratives of Kekkonen's feats of strength are an integral part of his 'mythology'. But the significance of sport was not limited to Kekkonen's public image; the president's bodily performances carried much weightier meaning. I argue that Kek- 
konen's able body protected the Finns from the uncertainties of the Cold War world, and this has made the myth of Kekkonen's superiority and invincibility so momentous and long-lasting.

\section{Sources and research literature}

Despite a plethora of literature on President Urho Kekkonen, there is a lack of analytic academic scholarship on him. The writings available consist mostly of reminiscences and political profiles created by Kekkonen's contemporaries, both by his closest men and his adversaries. These authors have their merits but they are somewhat partial and tend to pass politico-moral evaluations on Kekkonen. Because of the short temporal distance, even those earlier authors with more ambitious scientific aims have witnessed Kekkonen's era first-hand, and many of them have known him personally. Accordingly, they have also been affected by partiality and usually have passionate opinions about the president. For instance the work of Kekkonen's 'court historian' Juhani Suomi is indispensable as an overall account of the Kekkonen era, and usually is reliable in the depiction of political events. Yet, Suomi's scientific value is lessened by his tendency to glorify President Kekkonen. Although historiography can never reach objectivity, previous research on Kekkonen is exceptionally strongly slanted and distinctly divided into two camps either for or against him. (On the historiography on Kekkonen in more detail, see Tuikka 2007, 24-27.)

In recent years, a fresh generation of scholarship on Kekkonen has emerged. Some of the new researchers on the president are young enough not to have any personal experience or memories from the Kekkonen era. Even the rest of this group of scholars clearly distance themselves from the old patterns of 'Kekkonen studies', turning instead to novel perspectives and research problems. This paper belongs to the new wave of research on Kekkonen and is inspired by the search for fresh vantage points.

The most recent contributions to the study of Kekkonen have provided in-depth accounts of different aspects of the president's political life, but when it comes to the theme of research in this paper, they are of little help. Instead, I have to rely on earlier writings on the president, as they offer more comprehensive portrayals of his persona and also depict his sports hobbies. However, this literature does not challenge the view of Kekkonen as an invincible sportsman or discuss this image in a critical light but, quite the contrary, only consolidates it. Consequently, within this article, I do not separate earlier historians from more popular authors but refer to all previous literature on Kekkonen as my source material.

While the accounts of Kekkonen's sporting performances serve as sources, scholarship on men and masculinities functions as research literature and provides me with tools of analysis. Kekkonen gained success in sports, academia, politics and sexual conquest, all of 
which are typical arenas for demonstrating one's masculinity at least in modern Western societies. Not often can someone shine in all of them but President Kekkonen could with exceptional ease fulfil most requirements of this masculinity ideal. Quite surprisingly, Kekkonen has not been studied from the perspective of gender before, even though he was briefly touched upon in a pioneering work of Finnish men's studies (Lehtonen 1995).

The most obvious - but by no means the only - point of contact between Kekkonen and gender is (political) power. Power and masculinity are inseparably intertwined and, consequently, masculinity and politics are also connected. Politics has long been dominated by men and masculine discourses and still is 'heavily invested with heterosexual maleness' (Whitehead 2008, 234). But times change and so do politics. Interesting new scholarship shows how compassion and communication, albeit combined with toughness and strength, and a unisex or metrosexual style in male politicians increasingly appeal to voters (Cooper 2009, Messner 2007, Whitehead 2008). But these new requirements did not apply to President Kekkonen who governed Finland in the Cold War era. At that time, an aggressive and exaggerated form of masculinity ruled the political culture of the United States and, most likely, Finland as well (Dean 1998, Fahey 2007).

There is some, though not a superabundance of, research on men of power studied from the gender perspective. Especially in the U.S., scholars have pondered on the link between masculinity and political success and examined the utilization of masculine imagery in the acquisition and maintenance of political leaders' power (e.g. Christensen and Ferree 2008, Cooper 2009, Fahey 2007). Some researchers also add the body in the equation (e.g. Dean 1998, Messner 2007, Testi 1995); it is this field of study that I wish to contribute to with this paper.

Similarly to politics, the world of sport has shifted dramatically during the past couple of decades. The traditional bastion of aggressive hypermachismo now fosters more inclusive and emotional forms of masculinity. But, once again, President Kekkonen was influenced by a completely different atmosphere. In Kekkonen's time, a homophobic culture of hyper-masculine displays of strength still dominated the sports fields and most probably affected him as well (Adams et al. 2010, Anderson 2011). Nevertheless, we must not forget the positive, 'warm' side of sport that has always existed alongside the cold and ruthless one (Tiihonen 2002, 352). Obviously, Kekkonen did not just exploit his hobbies as a means of image-building but also genuinely enjoyed exercising, although I am inclined to underline the more negative aspects in my attempt to question the old 'truths' about the sporting president.

\section{A natural sportsman?}

Ever since he was a little boy, Urho Kekkonen enjoyed exercising outdoors. In his midtwenties, he was a top national-level athlete, and sport remained close to Kekkonen's 
heart throughout his life (Mäki 1975, Uino 1985). According to some, the president's leanings towards sport were inherited directly from his ancestors. This interpretation effectively constructs the myth of Urho Kekkonen as a natural-born sportsman. The supposed innateness suggests that Kekkonen's exercising was not only necessary but even compulsory for him. Physical exercise has indeed been depicted as no less than an integral part of Kekkonen's personality and sport as a cornerstone of his way of life. Exercising has been characterized as a basic need for Kekkonen, and if he could not carry out his daily keep-fit routine he felt almost physically ill (Kurjensaari 1967, Suomi 1998).

Raewyn Connell (1995, 2000), among others, has named sport as a central definer of modern Western masculinities. Performing, and indeed performing well, in sports fields has fundamental significance for the construction of a masculine identity. An active and capable male body carries great status value and sport can serve as a notable source of social capital (Wellard 2009). Success in sport as such brings respect but the highest value lies in natural talent. Brawn acquired through excessive workout and with the help of artificial supplements is of lesser worth than muscles trained by 'natural' methods. Breezing through a sports contest effortlessly generates more social capital than a performance squeezed out of the body with gritted teeth (Lahti 1992, Wellard 2009).

From the same source derives the notion that practising for competitions is unfair as it prevents true talent and perseverance from deciding the game (Knuutila 1992). Young Urho Kekkonen also represented this view in a causerie in the sports magazine Urheilulehti, in which he claimed that athletes should compete with little or no preparation so that all contestants would be on the same starting line and the one with greatest natural ability would win. Kekkonen himself had little interest or time to workout seriously and perhaps was frustrated to notice that his natural skills did not suffice without proper training. During his active career, Kekkonen had to practise like any other competing athlete, but performing without preparation would have better matched his ideal (Mäki 1975, Uino 1985).

As Michael Messner (1992) points out, sportsmen's claim of the naturalness of their talent is in stark contrast to the fact that they put a lot of work in developing their skills. Furthermore, they often regard their bodies as tools or machines to be utilized and used up in the process. According to Messner (1992), an instrumental view of one's body is connected to a tendency to take physical pain as a nuisance that has to be repressed (cf. Young et al. 1994). Anders Ahlbäck (2006) has depicted toughness and negligence towards the vulnerability of one's body as a typical masculine corporality in the modern western society. In athletic contests, men need to demonstrate not only their prowess but also their control over their bodies and their contempt for pain (Badinter 1993). Aches and pains are accepted as a part of the masculine lifestyle, and even despite injury, a good sport will not give up until it is physically impossible to do otherwise. Sportsmen are regarded as exemplars of good health while they in fact often suffer from permanent injuries and other physical problems. Sporting injuries are, however, worn with pride, as 
'battle scars' (Wellard 2009, 15, citing Young et al. 1994) or 'badges of masculine status' (Messner 1992, 76).

Jay Coakley (2004) identifies two distinct types of sporting practices: one model stresses pleasure and participation while the other emphasizes power and performance. Kekkonen seems to have better represented the latter model, which is characterized by a need to push one's limits and a tendency to view the body as a machine, risking its well-being in the quest for success. Naturally, both models can be present in one person simultaneously, and Kekkonen not only showcased his strength but also sought relaxation and recreation in his exercise hobbies. Furthermore, the president saw that physical exercise helped him to take care of his constitution. But in truth, Kekkonen's training habits were far from health promoting. He loved taking the most out of his body and pushing himself to the brink, which exposed his body to injury (Kurjensaari 1967). Once, for instance, he did twelve pull-ups instead of the regular eight and wrote in his diary afterwards that he was afraid of having caused a vascular rupture in his brain (Suomi 2001).

Kekkonen claimed that keeping in shape required a certain amount of self-torment (Mäki 1967). According to Anita Hallama (2001, 84), Kekkonen's long-time 'lady friend' $^{3}$, he was not happy with his performance on ski tracks unless he had skied dozens of kilometres streaming with sweat. Struggle and exertion have been depicted as sources of enjoyment for the president, who took great pleasure in surviving in difficult conditions. A story is told that even as a boy, he loved going out in the worst of storms, as if to challenge Nature itself. The symbolism here is obvious: during his decades in power, Kekkonen was often in the eye of political tempests, and surviving these gales with his head high must have been highly satisfactory to the president (Mäki 1967, Mäki 1975).

\section{Sport, power and pre-eminence}

The most important outdoor activities for President Kekkonen were hunting, fishing and cross-country skiing. In the winter, Kekkonen went skiing in the surroundings of his official residence Tamminiemi, and he also made yearly skiing trips to Lapland. In the summer, the president's favourite hobby was fishing. As a little boy he was already a keen angler and went fishing frequently until his last summer in office (Soikkanen 1998, Suomi 1998). People also regarded the president as an avid huntsman. This impression suited Kekkonen's active image well but, in fact, he was a poor shot. He nevertheless wanted to take part in hunts because they were important social gatherings. Kekkonen's power relied, to a great extent, on his wide network of personal contacts, with which he could influence decision-making on many levels and sides of the society. Unofficial occasions such as elk or pheasant hunts brought the members of the president's network together and provided the men of power with an opportunity for both light-hearted banter and more serious political talks (Soikkanen 1998, Soikkanen 2006). 
The president also utilized his fondness for outdoor hobbies in foreign politics and practised so-called 'fishing or hunting diplomacy' with the Soviet leaders. Kekkonen apparently believed that close and confidential contacts between the two countries' leaders would translate into friendly relations between their countries as well, and these kinds of links were best created in leisurely settings such as fishing and hunting trips. In an interview Kekkonen once stated that while fishing, no evil thoughts crossed the minds of fishers and, therefore, 'fishing diplomacy' was suited for advancing peace and averting aggressive intentions (Soikkanen 1998). Perhaps he truly thought that on fishing waters and hunting grounds, the Kremlin leaders would refrain from unfriendly power politics. In any case, Kekkonen felt that the great outdoors provided a natural surrounding for informal interaction and development of mutual understanding with the Soviets.

President Kekkonen used the great outdoors as a setting for wielding power and practising diplomacy. But sport also served as a building block of Kekkonen's power on a more profound level: I argue that, at least to a certain extent, Kekkonen's status and power were dependent on his active and able body and the displays he performed with it.

For example Badinter (1993), Connell (1995) and Kimmel (1996) have emphasized the performative nature of masculinity: men are supposed to enact their maleness through various bodily performances. Sports fields are important arenas in which these displays can be presented. While playing and competing, men can also signal their 'aggressiveness, competitiveness, power and assertiveness', which Ian Wellard has defined as 'expected sporting masculinity' (2009, 46-47; see also Adams et al. 2010 on orthodox masculinity).

While evidencing their sporting prowess, men can simultaneously display their masculinity. For this, they naturally need an audience. But the male body is accepted as an object of the gaze only in certain situations, for instance on sports fields, where the spectators' eyes focus not on the male body as such but on its activeness, strength and control. The reverse side of performativity is that masculinity becomes fragile and suspect if age, illness or disability prevents the successful presentation of the performance (Connell 1995, Lahti 1992). All of this resonates well with Kekkonen who very visibly demonstrated his manliness through sport. His office proudly informed the media of the president's exercise achievements, and the press loved covering Kekkonen's ski trips and other outdoor pursuits. The president's publicly celebrated sports hobbies seem to have served as feats of Kekkonen's strength, meant to testify to his sporting prowess and, thus, to his masculinity.

In the image and myth of President Kekkonen, a rational mind and an able body are integrally united. ${ }^{4}$ Both brainpower and muscular strength helped Kekkonen gather social status, and mental and bodily abilities supported each other as essential building blocks for his public persona. Kekkonen's seemingly superior physical condition - which he appeared to maintain over decades - bolstered his political power in a fundamental way. The deterioration of the president's health and his gradual ageing in the latter half of 
the 1970s were state secrets carefully concealed from the Finns. This serves at least as indirect evidence for the importance of Kekkonen's physique for his political stature. It seems as if the ageing president's power was in danger of collapsing completely if the actual state of affairs, i.e. the relatively normal, fluctuating condition of an ageing person, had been revealed to the general public.

No doubt self-control is of utmost importance for those men who also rule over others, although men and masculinity studies have emphasized the significance of control for the masculine identity in general. The manly body and identity have to have clear and controlled boundaries (Lehtonen 1995, Siltala 1994). Referring to Klaus Theweleit, Martti Lahti has described the closed, clear-cut and well-guarded body of a white western male as a symbol for social order and a shield against chaos (Lahti 1992). Applying this idea on Urho Kekkonen, we can view the president's tough and trained body as a shelter that protected the Finns, the 'children' of the father of the nation, from both domestic-political disputes and international storms of the Cold War. Thus, when Kekkonen's body began to slip from his grip, there was a risk that he would also lose his control over everything else, from the Soviet leaders to the decision-makers of the Finnish society.

President Kekkonen's sports performances alone, regardless of his success in them, were not enough to support his ascendancy. The case was not only about the president's exercise hobbies and their celebration in the media but, indeed, about Kekkonen's preeminence in them. According to his myth, Kekkonen was stronger and more capable than anyone else. The president's public sporting activities gave him the opportunity to showcase his superiority, and that is precisely why these hobbies were significant for his power position.

Kekkonen was a highly competitive sportsman and had a strong will to win. These qualities have been dated back to his childhood, and during his decades in politics, Kekkonen's competitiveness by no means diminished. The drive to contest and conquer remained strong until the end of Kekkonen's public career (Soikkanen 1998). Nevertheless, Kekkonen seems to have been dissatisfied with 'just' winning; it is often repeated that he had to be the best of the best and shine brighter than anyone else. The president appears to have been driven by the need to perform and succeed, and he always needed new evidence for his superiority to boost his ego (Kurjensaari 1967, Suomi 1998).

The president had plenty of opportunities to reassert his self-confidence. Judged by the stories by contemporaries, Kekkonen's fishing and skiing trips have first and foremost served the purpose of demonstrating Kekkonen's strength and supremacy. On fishing waters, Kekkonen wanted to have the most impressive catch of the day. Those who were able - or careless enough - to haul more fish than the president had to cover it up and downplay their catch. The most hilarious stories even mention the use of walkietalkies as a method of limiting the fishing party's take so as not to exceed Kekkonen's catch and aggravate him (Repo 1985, Soikkanen 1998). 
Similarly, Kekkonen made sure that he took the lead on ski tracks, and the president's day was ruined if everyone in the skiing party was able to keep up with his pace, let alone if someone could beat him (Mäki 1975). Despite Kekkonen's excellent skiing fitness, accidents could happen. An anecdote tells how Björn Westerlund, the CEO of Nokia Corporation, made the mistake of reaching the end of a 15-kilometre ski track before the president. Someone pointed out that Westerlund had put a foot wrong and should not have skied that fast. Fortunately, Westerlund was able to patch up his error by skiing really slow on the way back, and everything was fine again (Repo 1985).

At first, Westerlund's story and the use of walkie-talkies seem such gross exaggerations that they only evoke amusement. But on second thought, the radio phones, funny as they seem, reveal something surprising. They prove that the image of the seemingly pre-eminent Kekkonen was actually a fabrication: a tale consciously crafted and maintained by the president and his men. Kekkonen truly was a fit and capable sportsman but, at least in part, his superiority was nothing more than theatre. As everyone knew that the president had to be number one, they deliberately restrained themselves from beating him, which means that there was hardly any genuine competition to begin with (Repo 1985, Soikkanen 1998).

It follows that President Kekkonen was able to maintain his pre-eminence only if the members of his entourage - his simultaneous audience and co-actors - accepted the play and played along. The president desperately needed their support for his acts of power and manhood, because without this support, his performances of supremacy and supermasculinity would have become questioned and ridiculed. In the final analysis, then, the masculine image of the seemingly all-powerful President Kekkonen was in fact extremely fragile and under constant threat.

\section{The myth conserved}

The greatest danger to the performance of Kekkonen's superiority was time itself. In the mid-1970s, Kekkonen was at the height of his power and in 1978 he was elected for his fourth term with flying colours. But the president had been born in 1900 and simple mathematics proved that he was growing older. As the signs of the president's ageing became more apparent, his supremacy and super-masculinity could only remain intact if and as long as no one questioned them.

Juhani Suomi (2000) has suggested that the beginning of the end for Kekkonen's dominance was the defeat that he suffered to Prime Minister Mauno Koivisto in a battle of prestige in the spring of 1981. The controversy erupted when the president asked the prime minister to resign but the prime minister refused, invoking the constitution, a deed unheard of during Kekkonen's term. The president no longer had the strength to bring the government down, which was a setback he never recovered from. According to this interpretation, the man who had held Finland in his iron grip for a quarter of a cen- 
tury fell, albeit weakened by age, just because someone dared to defy his authority and challenge his power.

On the other hand, Suomi (1998) has also depicted how Kekkonen's condition slowly deteriorated over a long time. The decline was gradual and inconsistent but still undeniable. However, Kekkonen's tough physical condition effectively concealed his ageing until the late 1970s. In 1974, Kekkonen took a fitness test whose results claimed that his condition corresponded with that of a 40-year-old if not a 30-year-old. The press wrote enthusiastically about the results and portrayed Kekkonen as a virtual superman. The next year, the president retook the fitness test with a similar outcome but in 1977 and 1979, the test results remained unpublished (Sainio 1982, Suomi 1998).

The results of the first two tests probably were in accordance with reality but it is hard to take them literally. Kekkonen nevertheless did, or at least acted as if he did, and threw himself into obsessive exercising. According to Suomi $(1998,581)$, the meaning of skiing kilometres grew out of proportion and became 'proof of Kekkonen's virility'. He suggests that by documenting the kilometres meticulously in the diary, Kekkonen perhaps tried to convince himself that he was still alive, still in superior physical condition and still 'a mighty leader of his pack' (Suomi 1998, 580). ${ }^{5}$

Eventually, excessive strain took its toll and Kekkonen's body revolted. The president suffered from back and chest pain, arthritis, insomnia and occasional memory disorders (Suomi 2000). He interpreted the aches and pains as symptoms of ageing but was not going to give in to old age. Kekkonen obviously dreaded growing old and did not feel ready for it, even though he had to recognize his ageing and its consequences on his health and body (Suomi 2004). The president was by no means an exception: old people may admit their age but still externalize it on the surface of their body, unwilling or unable to adopt it as a part of their identity (Hänninen 2006).

Old age is a stage of life characterized by losses: loss of independence and autonomy, loss of mental performance, physical fitness and sexual prowess, loss of social status and activity - all of which are essential supporters of a masculine identity (Arber et al. 2003, Sandberg 2007). In the most brutal light, an old man is akin to a baby, a genderless creature at the mercy of others. This baby/aged man who just 'is' is in stark contrast with the ideal of an active and able male. Not surprisingly, then, adopting the identity of an elderly man is difficult or impossible for someone like Kekkonen who has been used to govern both himself and people around him with an iron fist (Hänninen 2006, Siltala 1994, Thompson 1994). Further difficulty is caused by the sense of replaceability, induced by retirement: a previously indispensable man suddenly becomes redundant and is substituted by someone new and younger (cf. Lehtonen 1995). President Kekkonen found it virtually impossible to let go of his office and status. He stubbornly hung on to his supposed indispensability and, over the years, became increasingly jealous and hostile towards his potential successor candidates. 
The researchers of ageing and masculinity want to emphasize that old age can offer men the opportunity to implement alternative masculinities and to break loose from the constant need to prove and perform their manliness (e.g. Hänninen 2006, Sandberg 2007). But for President Kekkonen and his public persona, ageing threatened to be the end of everything: he would turn from an invincible and irreplaceable superman to a mere mortal, from a powerful patriarch to a feeble old man.

Understandably, then, Kekkonen clung to the notion of his irreplaceability and to the displays of his able body as if they shielded him from the fear that he felt for giving up and losing his control, both over himself and over his realm. At the turn of the 1980s, however, the formerly obedient body began to slip from Kekkonen's grip. Like all those who reach high age, he was doomed to lose his battle against ageing. In September 1981, the president's poor health forced him to take sick leave, which finally ended with his early resignation from office in October. After this, Kekkonen and his condition collapsed quickly (Blåfield and Vuoristo 1982). In a heart-rending story from the time of his medical leave, Kekkonen tries to escape from his home but is stopped at the gate by his bodyguards. The contrast between the image of the former all-powerful president and the now weak and senile old man could hardly be any greater. Kekkonen spent his final years in his former official residence and died in August 1986 at the age of 85.

Kekkonen's indispensability was not just self-delusion. Many leading politicians and other influential people worried about the fate of Finland after Kekkonen, and it seemed difficult to find a suitable successor to fill his boots. Until the early 1980s, the easiest option was not to search for a successor at all but to continuously rely on Kekkonen. As the years passed, however, the ageing president needed more and more assistance to maintain his performance of superiority. Despite Kekkonen's faltering health, his closest men still carefully protected the image of the president as the 'perpetual moving machine of ski and jog tracks' (Sainio 1982, 43). They did not necessarily outright lie but they intentionally gave a misleading picture of Kekkonen's condition (Sainio 1982, 55).

Political reasons and/or personal interests probably motivated those involved to cover up Kekkonen's poor health. But, perhaps, something bigger was also at stake. Maybe they bent the truth at least partly because they felt that Finland was not ready to lose Kekkonen just yet. He was a protection against the great unknown; he was a constant in a world of instability and change. A huge number of Finns had never known any other president than Kekkonen, who thus was more like a monarch than an elected official. During his term, the country had developed towards rising living standards, widening social security and increasing international activity. But the future was uncertain and no one could be sure that development would continue as favourably as it had been during Kekkonen's time. The old president represented safety and security, and the Finns could not have known that everything would turn out just fine even without him and his shielding body. 
Of course, Kekkonen himself could not be protected against ageing and, eventually, the burden of years became too heavy on the president. The performance of his able body could no longer be sustained, and in the early autumn of 1981, Kekkonen's weakened condition became apparent to the general public through some eye-opening newspaper photographs (Soikkanen 1998). However, after Kekkonen's medical leave and resignation, the truth about his collapsed health was never revealed to the public.

Even after almost 30 years, we still know little about the president's final years. Kekkonen was enclosed within the walls of Tamminiemi and only a very limited number of family and staff members were in contact with him, while not even his closest friends were allowed to meet him any more (Sainio 1982). The public eye was turned from Kekkonen's deteriorating condition and decaying body to his former achievements, spirit and status (cf. Hänninen 2006, 72). Urho Kekkonen as a private person finally became old and fragile, but the myth of President Kekkonen was carefully conserved in 'the silence of Tamminiemi'. Kekkonen's concealment from the media was not only about allowing a frail old man to age with dignity or about protecting him from ruthless publicity. The case was also about keeping the myth of the omnipotent Kekkonen intact and unharmed by his ultimate weakness and mortality.

Since the 1980s, the public perception of Kekkonen has changed radically and become more multifaceted. Negative notions have emerged, and the legitimacy of his actions and ways of wielding power have been criticized. Yet, Kekkonen has also had a lot of proponents and sympathizers. Regardless of the outlook, Kekkonen has practically always been viewed as a man of (bodily) strength and (mental) power. Even though Kekkonen as a politician has been closely scrutinized and critically assessed, the myth of his might and masculinity has not really been questioned. Today, President Kekkonen is often regarded with a sense of irony (e.g. Lähdesmäki 2009), but even the jokes about him reproduce the image of Kekkonen as insuperable and invincible.

\section{Conclusion}

Physical exercise played a central role for President Kekkonen and served as an essential building block for his public image. Sports hobbies were a source of relaxation and recreation for the president but they also allowed him to showcase his able body and act out his masculinity. Furthermore, the president's pastime activities had wider, even nationallevel significance. First, he used outdoor trips and activities as instruments of decisionmaking and diplomacy. Second, Kekkonen's sports performances, and the bodily prowess he demonstrated through them, bolstered up his political status and power. With his sharp wit and able body, Kekkonen appeared to keep guard against both internal and external perils threatening his country. 
Although Kekkonen remained in exceptionally good shape for a long time, he eventually could not resist ageing and had to resign from office after a 25-year-term. But while Kekkonen as a private citizen became a frail old man, his public image remained one full of strength and power. A myth of Urho Kekkonen as an invincible superman was created during his term and carefully conserved after his fall from power, a myth that still affects our perception of the president.

As this paper shows, men and masculinity studies allow us to examine Urho Kekkonen and his pre-eminent façade in a new, more comprehensive light. The fruitful fusion of the gender perspective with Kekkonen reveals that even the seemingly seamless masculine image of such a powerful character as the president can actually be surprisingly vulnerable. Especially the study of the president as an ageing man desperately trying to prove his masculinity illuminates well the fragile and tragic side of Kekkonen's public persona. The relatively scant literature that exists on old men and later-life masculinities is even scarcer when it comes to discussions on the effects of ageing (bodies) on (men of) power. ${ }^{6}$ This article can only point out the need for and importance of further study on this complex issue and offer the example of President Kekkonen as an indication of the intricate interconnections between an ageing body, masculine image and political power.

Urho Kekkonen hopefully proves that a subject of traditional political history can be interesting in the eyes of men's historians and researchers on men and masculinities. Kekkonen does not represent subordinated or marginalized men but is instead a powerful and super-masculine character, a virtual embodiment of the hegemonic manliness of his time. But I find Kekkonen interesting precisely because of that. He demonstrates that even men of power have complicated and unstable masculinities and, thus, deserve our attention.

Examining a figure such as Kekkonen obviously runs the risk of shifting the focus back from women or marginalized males to powerful western white men, that is, the most conventional subjects of historical research (cf. Ditz 2004). However, the recent history of Finland cannot be understood without discussing Kekkonen and he is very likely to remain a popular subject for Finnish historians. Accordingly, I believe it must be an improvement to at least view Kekkonen explicitly and expressly as a man.

As Kate Murphy $(2010,36)$ has pointed out, '[t]he masculinity of great leaders and politicians is taken for granted and thus 'invisible' in the broader analysis of the character'. This state of affairs leaves us with a limited understanding of the most central actors and issues of political history. Policymakers are gendered beings and gender is an inseparable component of political discourses and processes. Consequently, '[r] esearch that makes men visible as gendered subjects thus has the capacity to deepen our understanding of the operation of power' and is worthy of conducting indeed (Murphy 2010, 25, cf. Dean 1998). So, if men of power cannot be overthrown from the core of historical research altogether, perhaps we could - and should - at least practise a new, gender-aware form of great men's history. 


\section{Acknowledgement}

I wish to thank Niklas Jensen-Eriksen, Kirsi Kinnarinen and the anonymous referees for their invaluable feedback on the earlier drafts of this paper.

\section{Notes}

1 Helsingin Sanomat quoted President Kekkonen's profile and interview published in Le Monde on 23 October 1962. Translation from Finnish by the author.

2 From March 1956 until September 1981 or, officially, until January 1982.

3 Over the decades, President Kekkonen had several affairs that were open secrets in Finland. To this day, they remain a subject that fascinates but is, simultaneously, dealt with great discretion. Quite tellingly, Kekkonen's mistresses are still referred to as 'lady friends'.

4 The union of muscle and mind has been emphasized with regard to, among others, Theodore Roosevelt, Benito Mussolini and John F. Kennedy (e.g. Bederman 1995, Dean 1998, Testi 1995). This might suggest that a form of masculinity that seamlessly combines both mental and physical abilities is (or at least has been) most valuable for political leaders.

5 Quotes from Finnish translated by the author.

6 Despite increasing academic interest in ageing men and their masculinities in recent years (e.g. Arber et al. 2003, Calasanti and King 2005, Thompson 2006), the theme of older males and power has largely remained untouched. Hearn (2007) and Sandberg (2007) are among the rare examples who have pondered on the issue, but neither one deals with ageing men of power as such.

\section{References}

Adams, Ali, Anderson, Eric and McCormack, Mark. 2010. Establishing and challenging masculinity: The influence of gendered discourses in organized sport. Journal of Language and Social Psychology 29(3), 278-300.

Ahlbäck, Anders. 2006. Den beväpnade manligheten. Kön och nationalism i det mellankrigstida Finlands värnpliktsarmé 1919-1939. Turku: Åbo Akademi.

Anderson, Eric. 2011. Masculinities and sexualities in sport and physical cultures: Three decades of evolving research. Journal of Homosexuality 58(5), 565-578.

Arber, Sara, Davidson, Kate and Ginn, Jay. 2003. Changing approaches to gender and later life. In Arber, Sara, Davidson, Kate and Ginn, Jay (eds.) Gender and ageing: Changing roles and relationships. Maidenhead: Open University Press, 1-14.

Badinter, Elisabeth. 1993. Mikä on mies? Tampere: Vastapaino.

Bederman, Gail. 1995. Manliness \& civilization: A cultural history of gender and race in the United States, 1880-1917. Chicago: University of Chicago Press.

Blåfield, Antti and Vuoristo, Pekka. 1982. Kun valta vaihtui. Mitä todella tapahtui presidentinvaaleissa 1982. Helsinki: Kirjayhtymä.

Calasanti, Toni and King, Neil. 2005. Firming the floppy penis: Age, class, and gender relations in the lives of old men. Men and Masculinities 8(1), 3-23.

Christensen, Wendy M. and Ferree, Myra Marx. 2008 Cowboy of the world? Gender discourse and the Iraq war debate. Qualitative Sociology 31(3), 287-306.

Coakley, Jay. 2004. Sport in Society (8th edition). Boston \& New York: McGraw-Hill.

Collins, Rebecca. 2003. Concealing the poverty of traditional historiography: Myth as mystification in historical discourse. Rethinking History 7(3), 341-365.

Connell, R. W. 1995. Masculinities. Cambridge: Polity Press.

Connell, R. W. 2000. The men and the boys. Cambridge: Polity Press. 
Cooper, Frank Rudy. 2009. Our first unisex president? Black masculinity and Obama's feminine side. Denver University Law Review 86(3), 633-661.

Dean, Robert D. 1998. Masculinity as ideology: John F. Kennedy and the domestic politics of foreign policy. Diplomatic History 22(1), 29-62.

Ditz, Toby L. 2004. The new men's history and the peculiar absence of gendered power: Some remedies from early American gender history. Gender \& History 16(1), 1-35.

Fahey, Anna Cornelia. 2007. French and feminine: Hegemonic masculinity and the emasculation of John Kerry in the 2004 presidential race. Critical Studies in Media Communication 24(2), 135-150.

Hallama, Anita. 2001. Sydämen kieltä sydämelle. Helsinki: Otava.

Halpin, Tony. 2009. Bare-chested Vladimir Putin strikes a macho pose. The Times, 5 August 2009. Retrieved 27 June 2011, from: http://www.timesonline.co.uk/tol/news/world/europe/article 6738969.ece.

Hearn, Jeff. 2007. Men, ageing and power: Can men's ageing challenge patriarchy? In Fahlgren, Siv and Thurén, Britt-Marie (eds.) Genusmaraton 2007. Mittsveriges genusforskare på frammarsch (Genusstudier vid Mittuniversitetet 1). Sundsvall: Mittuniversitetet, 71-79.

Heehs, Peter. 1994. Myth, history, and theory. History and Theory 33(1), 1-19.

Herlin, Ilkka. 1993. Kivijalasta harjahirteen. Kustaa Vilkunan yhteiskunnallinen ajattelu ja toiminta. Helsinki: Otava.

Hänninen, Jorma. 2006. Vanhan miehen ruumis ja hegemoninen maskuliinisuus. Gerontologia 20(2), 67-74.

Jokisipilä, Markku. 2005. Suomalainen historiallinen myytti. Tieteessä tapahtuu 23(2), 16-22.

Kanerva, Jukka. 1994. 'Ryvettymisen hyvä puoli.' Suomalainen politiikka ja poliitikot televisiossa (Nykykulttuurien tutkimusyksikön julkaisuja 40). Jyväskylä: University of Jyväskylä.

Kimmel, Michael. 1996. Manhood in America: A cultural history. New York: The Free Press.

Knuutila, Seppo. 1992. Häviämisen häpeä. In Sironen, Esa, Tiihonen, Arto and Veijala, Soile (eds.) Urheilukirja. Tampere: Vastapaino, 87-96.

Kurjensaari, Matti. 1967. Seurasaaren sillalla. In Mäki, Tauno V. and Levo, Urpo (eds.) Presidentti eräretkillä. Helsinki: Tammi, 9-15.

Lahti, Martti. 1992. Vajaat ja ylettömät - maskuliinisuus ja miehen ruumis. Naistutkimus 5(2), 6-18.

Lehtonen, Mikko. 1995. Pikku jättiläisiä. Maskuliinisuuden kulttuurinen rakentuminen. Tampere: Vastapaino.

Lähdesmäki, Tuuli. 2009. From personality cult figure to camp image: The case of president Urho Kekkonen. Participations: Journal of Audience \& Reception Studies 6(1), 52-76.

Messner, Michael A. 1992. Power at play: Sports and the problem of masculinity. Boston: Beacon Press.

Messner, Michael A. 2007. The masculinity of the governator: Muscle and compassion in American politics. Gender \& Society 21(4), 461-480.

Murphy, Kate. 2010. Feminism and Political History. Australian Journal of Politics and History 56(1), 21-37.

Mäki, Tauno V. 1967. Hiihtäen kairojen halki. In Mäki, Tauno V. and Levo, Urpo (eds.) Presidentti eräretkillä. Helsinki: Tammi, 65-80.

Mäki, Tauno V. 1975. Iloista kyytiä päämiehen mukana kairassa ja tunturissa. Helsinki: Otava.

Osborn, Andrew. 2010. 'Macho man' Vladimir Putin races a Formula One car. The Telegraph, 7 November. Retrieved 17 June 2011, from: http://www.telegraph.co.uk/news/worldnews/europe/russia/8116178/Macho-man-Vladimir-Putin-races-a-Formula-One-car.html.

Pajunen, Veikko I. 1962. Kekkosella ei ole sanomaa Hrushtshevilta de Gaullelle. Helsingin Sanomat, 24 October. 
Parfitt, Tom. 2010. Vladimir Putin goes hunting to 'beef-up action man' image. The Guardian, 25 August. Retrieved 27 June 2011, from: http://www.guardian.co.uk/world/2010/nov/01/ vladimir-putin-action-man-images?.

Repo, Eino S. 1985. Päämies. Henkilökuva Urho Kekkosesta hänen presidenttiajaltaan. Espoo: Weilin+Göös.

Sainio, Pentti. 1982. Mitä tapahtui Urho Kekkoselle? Viimeiset vaiheet presidenttinä (2nd edition). Porvoo, Helsinki \& Juva: WSOY.

Sandberg, Linn. 2007. Ancient monuments, mature men and those popping amphetamine: researching the lives of older men. NORMA: Nordic Journal for Masculinity Studies 2(2), 86-104.

Siltala, Juha. 1994. Miehen kunnia. Modernin miehen taistelu häpeää vastaan. Helsinki: Otava. Soikkanen, Mauri. 1998. Urho Kekkonen. Kovettu kalamies. Jyväskylä \& Helsinki: Gummerus. Soikkanen, Mauri. 2006. Kekkosen kanssa metsällä ja kalalla. Helsinki: Gummerus.

Suomi, Juhani. 1998. Urho Kekkonen 1972-1976. Liennytyksen akanvirrassa. Helsinki: Otava. Suomi, Juhani. 2000. Urho Kekkonen 1976-1981. Umpeutuva latu. Helsinki: Otava.

Suomi, Juhani (ed.). 2001. Urho Kekkosen päiväkirjat 1. 1958-62. Helsinki: Otava.

Suomi, Juhani (ed.). 2004. Urho Kekkosen päiväkirjat 4. 1975-81. Helsinki: Otava.

Testi, Arnaldo. 1995. The gender of reform politics: Theodore Roosevelt and the culture of masculinity. The Journal of American History 81(4), 1509-1533.

Thompson, Edward H. 1994. Older men as invisible men in contemporary society. In Thompson, Edward H. (ed.) Older men's lives. Thousand Oaks, CA: Sage, 1-21.

Thompson, Edward H. 2006. Images of old men's masculinity: Still a man? Sex roles 55(9/10), 633-648.

Tiihonen, Arto. 2002. Ruumiista miestä, tarinasta tulkintaa: oikeita miehiä - ja urheilijoita? (Liikunnan ja kansanterveyden julkaisuja 134). Jyväskylä: Liikunnan ja kansanterveyden edistämissäätiö LIKES.

Tuikka, Timo J. 2007. 'Kekkosen konstit.' Urho Kekkosen historia - ja politiikkakäsitykset 1933 1981 (Jyväskylä studies in humanities 70). Jyväskylä: University of Jyväskylä.

Uino, Ari. 1985. Nuori Urho Kekkonen. Poliittisen ja yhteiskunnallisen kasvun vuodet (1900-1936). Helsinki: Kirjayhtymä.

Wellard, Ian. 2009. Sport, masculinities and the body. New York \& London: Routledge.

Whitehead, Stephen. 2008. Metrosexuality! Cameron, Brown and the politics of 'new masculinity'. Public Policy Research 14(4), 234-239.

Young, Kevin, White, Philip and McTeer, William. 1994. Body talk: Male athletes reflect on sport, injury, and pain. Sociology of Sport Journal 11(2), 175-194.

Maiju Wuokko, M.A., is a doctoral student of Finnish and Nordic History at the Department of Philosophy, History, Culture and Art Studies at the University of Helsinki. In her doctoral thesis she examines the Finnish presidential elections of 1982 in which a successor for Urho Kekkonen was selected. In addition, she has written about President Kekkonen from the perspective of men and masculinity studies and is interested in the interconnections between gender, power and ageing. 